\title{
The role of matrix metalloproteinases in pathogenesis of human bladder cancer
}

\author{
Tomasz Wiśniowski ${ }^{1}$ Jarosław Bryda², Jacek Kurzepa ${ }^{3}$ and Sławomir Wątroba4⿴囗十 \\ 1Department of Urology and Urological Oncology, St. John of God Independent Public Provincial Hospital, Lublin, Poland; 2Department of \\ Veterinary Hygiene, Voivodship Veterinary Inspectorate, Lublin, Poland; ${ }^{3}$ Department of Medical Chemistry, Medical University, Lublin, Poland; \\ ${ }^{4}$ Department of Neonatology and Neonatal Intensive Care Unit, Independent Public Healthcare, Puławy, Poland
}

\begin{abstract}
Matrix metalloproteinases (MMPs) play an important role in many physiological and pathological processes, including neoplastic processes. They belong to a group of enzymes called endopeptidases and have the ability to hydrolyze all proteins in the extracellular matrix (ECM). They are produced in most connective tissue cells, macrophages, leukocytes, endothelial cells, microglial cells and in cancer cells. Neoplastic diseases are one of the main causes of death in Poland and in the world, therefore learning about the process of carcinogenesis seems to be particularly important. The process of carcinogenesis is currently widely studied and MMPs play one of the key roles in the development of cancer. They do this by regulating local tumor growth, stromal invasion, stimulating angiogenesis and metastasis formation. Bladder cancer is the 7th most common cancer in the male population and the 11th most common cancer in the world. In bladder cancer, most studies have been devoted to MMP-2 and MMP-9, that are enzymes responsible for the degradation of type IV collagen in the first place, which through the destruction of basement membranes and ECM, play an essential role in the tumor invasion process. Since bladder cancer is characterized by the ability to relapse, from the point of view of clinical practice it seems particularly important to develop a marker of early bladder tumor recurrence. MMPs detected in the urine and serum of patients with bladder cancer are potential factors that could play such a role.
\end{abstract}

Keywords: matrix metalloproteinases, tissue inhibitors of metalloproteinases, bladder cancer, carcinogenesis, angiogenesis

Received: 24 January, 2021; revised: 31 January, 2021; accepted: 17 April, 2021; available on-line: 27 July, 2021

๑e-mail: watrobaslaw@gmail.com

Abbreviations: AIDS, acquired immune deficiency syndrome; CAF cancer-associated fibroblasts; CIS, carcinoma in situ (ang. intraepithelial neoplasia); ECM, extracellular matrix; EGF, epidermal growth factor; EMMPRIN, extracellular matrix metalloproteinase inducer; EMT, epithelial-mesenchymal transition; EPO, erythropoietin; FDA, Food and Drug Administration; FGF- $\beta 2$, fibroblast growth factors type $\beta 2$; GPI, glycophosphatidylinositol; HIF-1, hypoxia-inducible factor 1; IL-1, interleukin 1; IL-10, interleukin 10; IL-12, interleukin 12; IL-1ß, interleukin-1ß; IL-6, interleukin 6; IL-8; CXCL-8, interleukin 8; INF- $\gamma$, interferon $\gamma$; MMPs, matrix metalloproteinases; MT-MMPs, membrane-type of MMPs; PDGF, platelet-derived growth factor; $\mathrm{RA}$, rheumatoid arthritis; $\mathrm{RX}(\mathrm{R} / \mathrm{K}) \mathrm{R}$, furin recognition motif; SPARC, secreted protein acidic and rich in cysteine; TAM, tumor-associated macrophage; TAM-M1, tumor-associated macrophage type M1; TAM-M2, tumor-associated macrophage type M2; TGF- $\beta 1$, transforming growth factor $\beta 1$; TIMPs, tissue inhibitors of metalloproteinases; TNF-a, tumor necrosis factor a; VEGF, vascular endothelial growth factor; VEGF-R2, vascular endothelial growth factor - type 2 receptor

\section{INTRODUCTION}

Biochemically, extracellular matrix metalloproteinases (MMPs) belong to a group of enzymes called endopeptidases and have the ability to hydrolyze all extracellular matrix proteins (ECM). They are produced in most connective tissue cells, macrophages, leukocytes, endothelial cells, microglial cells and, importantly, also in neoplastic cells (Deryugina \& Quigley, 2006; Page-McCaw et al., 2007; Fic et al., 2011). MMPs play an important role in physiological and pathological processes, taking part in initiating and regulating inflammatory and carcinogenic processes, and also play a significant role in embryogenesis and organ maturation (Deryugina \& Quigley, 2006; Fic et al., 2011; Watroba et al., 2019). The role of MMPs in the pathological processes of fibrosis in liver cirrhosis, the development of bronchopulmonary dysplasia in preterm neonates, as well as in the degeneration of articular cartilage in rheumatoid arthritis (Mądro et al., 2012; Bryda \& Wątroba, 2018; Wątroba \& Bryda, 2019).

\section{CHARACTERISTICS OF MATRIX METALLOPROTEINASES}

MMPs contain a zinc ion in their structure and their typical components are propeptide that inhibits catalysis by blocking the active centre and the catalytic domain, which is responsible for the hydrolysis of peptide bonds of a given substrate (Kurzepa et al., 2014). The socalled hinge region or hemopexin-like domain are nonpermanent components of MMPs (Lipka et al., 2008). The regulation of the activity of MMPs is under the constant control of tissue inhibitors of metalloproteinases (TIMPs), which form non-covalent complexes with MMPs in the ratio 1:1 (Brew et al., 2000; Fic et al., 2011).

TIMP-1 is structured as an alkaline glycoprotein of 184 amino acids with a molecular weight of $28 \mathrm{kDa}$ (Murphy et al., 1991). TIMP-1 has an inducible expression mechanism, and its synthesis is stimulated by erythropoietin (EPO), tumor necrosis factor $\alpha(\mathrm{TNF}-\alpha)$, interleukin-1 $\beta$ (IL-1 $\beta$ ) and platelet (PDGF) and epithelial (EGF) growth factors (Arza et al., 2001; Brew \& Nagase, 2010). The primary function of TIMP-1 is to inhibit the activity of MMPs by forming non-covalent bonds with both the active and inactive forms (Brew et al., 2000; Brew \& Nagase, 2010).

TIMP-2 is a protein composed of 194 amino acids with a molecular weight of $21 \mathrm{kDa}$, which is characterized by a constitutive expression mechanism and has the ability to block the activity of both MMP-2 and MMP-9 and has an influence on growth factor-dependent induction of mitogenesis (Ozenci et al., 1999; Lambert et al., 2004; Kim et al., 2015). 
TIMP-3 is an insoluble polypeptide with a molecular weight of $30 \mathrm{kDa}$ and has the lowest inhibitory activity for MMP-2, -3, -7 and -9 and also has anti-angiogenic activity (Palosaari et al., 2003; Chetty et al., 2008). TIMP-3 has an inducible expression mechanism and inhibits the activity of most matrilisins, gelatinases and collagenases (Gill et al., 2003; Trojek, 2012; English et al., 2018).

Regulation of biological activity of MMPs depends on gene transcription, proenzyme activity and TIMPs activity. The ability to initiate MMPs expression have IL-1 $\beta$, TNF- $\alpha$, interleukin 6 (IL-6), interleukin 8 (IL-8, CXCL8), lectin and extracellular MMP inducers (EMMPRIN) (Opdenakker et al., 2001; Schmidt et al., 2006).

MMPs are secreted into the ECM in the form of inactive proenzymes and their activation takes place in two stages, including a reversible process based on the principle of a "cysteine switch" and not related to the separation of the propeptide, and the irreversible process of permanent separation of the propeptide catalyzed by proteolytic enzymes (Fig. 1) (Mott \& Werb, 2004; Okamoto et al., 2004; Kim \& Hwang, 2011; Kapoor et al. 2016; Franco et al., 2017).

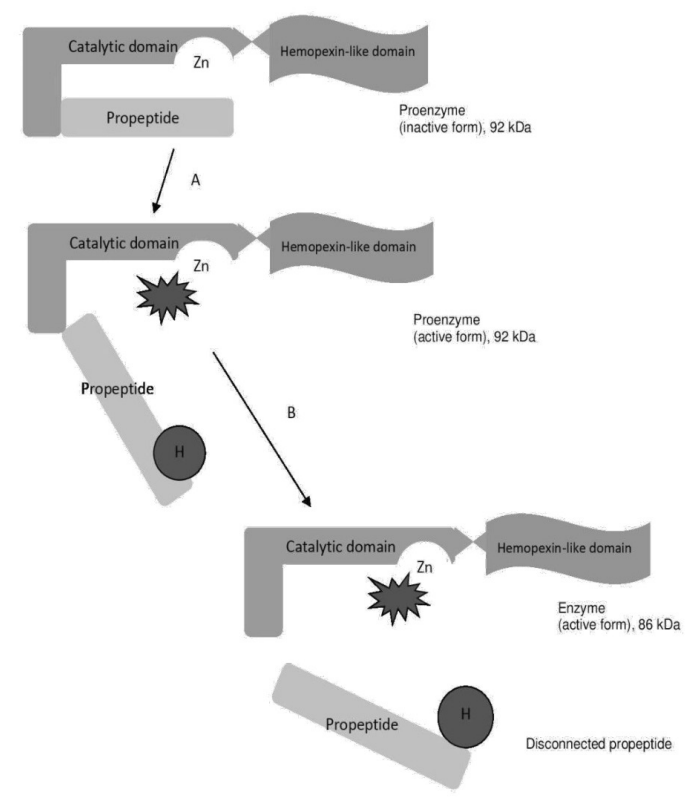

Figure 1. Diagram of the structure and activation of the MMP proenzyme (on the example of MMP-9).

The domains present in the gelatinases are: propeptide, a catalytic domain with a zinc atom ( $Z n)$, a hinge region and a hemopexinlike domain. A - non-proteolytic activation using mercury $(\mathrm{Hg})$ compounds or some denaturing compounds. During this process, there is no disconnection of the propeptide (no change in mass in relation to the proenzyme). If the propeptide activating agent is removed, the propeptide rejoins the active site preventing catalysis (,cysteine switch"). B - proteolytic activation involves the detachment of the propeptide. It is an irreversible process associated with a reduction in the mass of the enzyme by the mass of the propeptide (Wątroba et al., 2021 modified).

\section{GELATINASES (MMP-2, -9)}

They belong to the group of MMPs with the ability to degrade gelatine (Bauvois, 2012). They have a fibronectin-like hydrophobic fragment and a domain that is structurally similar to type $\mathrm{V}$ collagen (Kurzepa et al., 2014). The molecular weight of the latent form of MMP-2 (pro-MMP-2) is $72 \mathrm{kDa}$ and that of proMMP-9 is $92 \mathrm{kDa}$ (Opdenakker et al., 2001; Verslegers et al., 2013). The molecular weights of the proteolytically activated MMP-2 and MMP-9 are $66 \mathrm{kDa}$ and $86 \mathrm{kDa}$ respectively, and their primary substrate is type IV collagen, which is part of the basement membrane of the endothelium (Opdenakker et al., 2001; Kurzepa et al., 2014). Additionally, gelatinases have the ability to bind laminin, aggrecan, elastin and fibronectin, and activate pro-inflammatory cytokines such as IL- $8, \mathrm{IL}-1 \beta$, and TNF- $\alpha$ (Opdenakker et al., 2001; Wątroba et al., 2019).

\section{COLLAGENASES (MMP-1; $-8 ;-13,-18$ )}

In their structure, collagenases contain the hemopexin domain combined with the catalytic domain and show the ability to degrade entactin, fibronectin, aggrecan and almost all collagen subtypes (Loftus et al., 2002).

\section{MATRILYSINS (MMP-7, -26)}

Matrilysins are the smallest group among all MMPs and are classified as endometalloproteinases. They do not have a hemopexin domain in their structure and their catalytic activity includes the degradation of fibronectin, fibrinogen, and type IV collagen. In humans, they are a marker of the degree of malignancy of breast and lung cancer, while MMP-7 plays a role in the destabilization of atherosclerotic plaque and its activity positively correlates with the degree of heart failure (Bolon et al., 1997; Galis \& Khatri, 2002; Lipka et al., 2008; Wysocka et al., 2014).

\section{STROMELYSINS (MMP-3, -10, -11)}

Stromelysins are structurally similar to gelatinases. In addition to the structural constants typical of MMPs, it has a hemopexin-like domain along with a hinge region (van Hove et al., 2012). MMP-3 plays the role of apoptotic processes, regulation of gene expression and modelling of the cytoskeleton, and also has the ability to activate other pro-forms of MMPs, such as pro-MMP-1, $-3,-7,-8,-9,-13$, which accelerate the degradation of extracellular proteins not only by MMP-3 but also by activation of pro-MMP-9 (Cauwe \& Opdenakker, 2010). MMP-10 is $85 \%$ similar to MMP-3 in terms of the amino acid composition of the catalytic domain and has a similar substrate spectrum. It plays a role in the processes of angiogenesis and regulation of the maturation of the skeletal system (Batra et al., 2012). MMP-11 can be activated intracellularly through the furin recognition motif of $\mathrm{RX}(\mathrm{R} / \mathrm{K}) \mathrm{R}$ present on its C-terminal fragment and its biological role is not fully understood (Nagase et al., 2006; Yang et al., 2016).

MEMBRANE TYPE OF MMPS - MT-MMPS (MMP-14, -15, $-16,-17,-24,-25)$

MT-MMPs include a group of enzymes functionally and structurally related to elements of plasmalemma, some of them belong to type I membrane proteins (MMP-14, MMP-15, MMP-16, MMP-24), while others are glycophosphatidylinositol (GPI) related proteins. Apart from MMP-17, enzymes from this group are necessary in the MMP-2 activation process, while MMP14 plays an important role in the angiogenesis process (Wysocka et al., 2014). 


\section{OTHER MMPS (MMP-12, -19, -20, -21, -28)}

This group includes enzymes which, due to their structures and functions, cannot be classified into other groups. Enamelysin (MMP-20) plays an important role in the process of tooth enamel embryogenesis and inhibition of its activity with congenital enamel hypoplasia ( $\mathrm{Lu}$ et al., 2008). MMP-19 activity has been found in the synovial vessels in the rheumatoid arthritis (RA), while epilysin (MMP-28), present in keratinocytes, plays a role in the process of hemostasis (Manicone et al., 2011; Chang et al., 2018).

\section{THE ROLE OF MATRIX METALLOPROTEINASES IN CARCINOGENESIS}

MMPs play an important role in many physiological and pathological processes, including neoplastic processes (Kwiatkowski et al., 2009). Neoplastic diseases are one of the main causes of death in Poland and in the world, therefore learning about the carcinogenesis process seems to be particularly important. Despite numerous attempts to implement targeted therapy in neoplastic diseases, mortality in about $90 \%$ of cancer patients is a result of metastatic disease development and cell resistance to available therapeutic agents (Dofara et al., 2020).

The first work dealing with the problem of carcinogenesis and cancer formation is considered to be the one written by Percivall Pott in 1775, assessing the influence of carbon black on the risk of scrotal cancer in chimney sweeps (Peters \& Gonzalez, 2018).

The carcinogenesis process is currently widely studied and MMPs play one of the key roles in cancer development. They do this by regulating local tumor growth, stromal invasion, promoting angiogenesis and metastasis formation. There are usually 4 stages in the carcinogenesis process: initiation, promotion, progression, and metastasis. MMPs take part in each of them (Pittayapruek et al., 2016; Chojnacki et al., 2017). The pathway for cancer cells to metastasize is very complex. In the primary tumor microenvironment, under the influence of numerous factors such as hypoxia, acidosis and with the participation of numerous inflammatory cytokines, well-differentiated epithelial cells transform into undifferentiated mesenchymal cells capable of migration. This process is called the epithelial-mesenchymal transition (EMT) (Valastyan \& Weinberg, 2011).

In normal tissues, there is an ongoing interaction between cells and ECM, which takes place through direct cell-cell contact and through numerous chemokines, growth factors, and cytokines that regulate tissue homeostasis. In the neoplastic process, this homeostasis is disturbed at an early stage. Neoplastic cells secrete enzymes, including MMP-1, MMP-2, MMP-9, which have a destructive effect on the ECM and synthesize transforming growth factor type $\beta 1$ (TGF- $\beta 1$ ), fibroblast growth factor type $\beta 2$ (FGF- $\beta 2$ ), interleukin 1 (IL-1), IL-6 that recruit and are involved in the transformation of other stromal cells (Taddey et al., 2013).

Cancer-associated fibroblasts (CAFs) play a special role among the cells involved in local tumor progression. When CAFs are active, they can release signalling molecules that stimulate tumor growth. CAFs emit, among others collagen, fibronectin, and MMP-1, MMP-3, MMP7, MMP-9, MMP-13, which in turn can release other growth factors contained in the ECM, such as vascular endothelial growth factor (VEGF). In addition, CAFs form the pathways by which cancer cells can migrate with CAFs (Bremnes et al., 2011).

Tumor-associated macrophages (TAMs) are another important extracellular matrix cells involved in tumor development. In the microenvironment of tumors, they appear in two forms with different functions. TAMs type M1 (TAMs-M1) play an anti-tumor and immunostimulatory role by secreting interferon $\gamma(\mathrm{INF}-\gamma)$ and interleukin 12 (IL-12), while TAMs type M2 (TAMs-M2) act immunosuppressive and through the secretion of interleukin 10 (IL- 10) enhance angiogenesis and the secretion of MMP-1, MMP-3, and MMP-14, promoting tumor development (Räsänen \& Vaheri, 2010).

Cancer cell invasion is a complex process by which MMPs are involved in the degradation of ECM elements and the basal membranes surrounding the primary tumor. Impairment of the adhesive properties between cells and the reorganization of the cytoskeleton promote the migration of cancer cells and infiltration of the stroma. The reorganization of the ECM matrix by MMPs causes the release of their cytokines and chemokines, which then affect cancer cells (Pittayapruek et al., 2016).

Numerous immunohistochemical studies have shown that in brain tumors of particularly high malignancy, such as gliomas, a much higher expression of MMPs is found compared to normal tissue. Similar conclusions can be found in the study of laryngeal cancer, which also confirms the relationship between the degree of MMPs expression and the growth rate and invasiveness of the tumor (Grzelczyk et al., 2016; Chojnacki et al., 2017; Zhou et al., 2019).

In breast, kidney, prostate, and colorectal cancers, the correlation between the degree of expression of genes encoding MMPs proteins and the appropriate TIMPs, and some unfavourable prognostic factors, such as the clinical advancement of the tumor, grading, metastasis, relapse-free time, and overall survival, was confirmed (Grzelczyk et al. al., 2016).

Gelatinases, including MMP-9, which are involved in the remodelling of the ECM, play a particularly important role in the invasion of neoplastic cells and the development of the primary tumor. Many types of cells are capable of synthesizing and secreting MMP-9, including macrophages, neutrophils, fibroblasts, and endothelial cells. MMP-9 allows the degradation of collagen of basement membranes, including type IV collagen. This destruction is a key element in the invasion and formation of metastasis by cancer cells. Increased expression of MMP-9 generally promotes the development of the neoplastic process, although it may also play a suppressive role, as in the case of colorectal cancer developing in the course of colitis ulcerosa (Huang, 2018).

MMP-2 is secreted mainly by fibroblasts and other fibroblast-like stromal cells. MMP-2, through its proteolytic activity, takes part in the creation of a microenvironment that promotes the proliferation of cancer cells. This includes the elimination of adhesion molecules such as adherins and integrins, and the remodelling of the cytoskeleton, allowing the separation of neoplastic cells from the primary tissue. Of all the adhesion molecules, it is the loss of e-cadherin expression on the surface of cancer cells that appears to be a key component of EMT. E-cadherin as a transmembrane glycoprotein protects intercellular contacts, playing a key role in the adhesion of epithelial cells. It has been observed that the decrease in e-cadherin expression in breast, endometrial, bladder, colon and oesophageal cancer is associated with a more severe course of the disease and a worse prognosis (Sun et al., 2018; Gonzalez et al., 2019; Song et al., 
2019). MMP-3 and MMP-7 directly cleave the e-cadherin domain, releasing an $80 \mathrm{kDa}$ fragment involved in inhibiting cell adhesion and stimulating cell invasion by a paracrine mechanism (Singh et al., 2017).

\section{THE ROLE OF MATRIX METALLOPROTEINASES IN CANCER ANGIOGENESIS}

Angiogenesis allows the primary tumor to grow. The process involves creating a network of new blood vessels, thanks to which the tumor gains constant access to nutrients and can release harmful waste products. In addition, the emerging new, pathological blood vessels favour the migration of cells into the lumen of the vessels and the formation of distant metastases (Deryugina \& Quigley, 2015; Chojnacki et al., 2017).

According to the commonly prevailing view on angiogenesis within the primary tumor, new vessels that are formed there are structurally and functionally immature. The tumor vascular network is chaotic, tortuous, abnormal in diameter, abundant with pericyte defects, and is lined by highly permeable and abnormal endothelial cells (Deryugina \& Quigley, 2015; Zhou et al., 2019).

Changes occurring in the microenvironment of the primary tumor, such as hypoxia, acidosis, anaerobic metabolism, nutrient deficiency, stimulate the secretion of angiogenic factors. The described processes also increase the expression of MMPs, including MMP-9 secreted by tumor cells, TAMs, and neutrophils. MMP-9 in turn causes the release of VEGF found in the ECM and activates FGF- $\beta 2$ with a strong pro-angiogenic effect (Noë et al., 2001).

Many molecular factors directly or indirectly influence the process of angiogenesis induced by neoplastic cells. VEGF plays a key role in this aspect (De Bocket al. 2011). There is a functional link between VEGF and MMPs in the angiogenesis process. Expression of VEGF and MMP-9 can be induced simultaneously at the level of transcription by type 1 hypoxia induction factor (HIF-1) (Pittayapruek et al., 2016).

During tumor growth, its demand for oxygen increases, which leads to local tissue hypoxia, and in order to adapt to local conditions neoplastic cells increase the synthesis and secretion of HIF-1 (Pittayapruek et al., 2016). Moreover, hypoxia induces the expression of numerous MMPs as found with MMP-1, MMP-2, MMP3, MMP-7, MMP-9, MMP-10, and MMP-13 (Ardi et al., 2009). The activity opposite to tissue hypoxia is performed by secreted protein acidic and rich in cysteine (SPARC), which simultaneously inhibit the regulation of VEGF and MMP-9, which in the medulloblastoma model leads to the development of smaller tumors and a sparse vascular network (Bhoopathi et al., 2010).

Similar conclusions were observed in gastric cancer, where it was found that SPARC inhibit the expression of VEGF and MMP-7, while increased VEGF expression is associated with the overexpression of MMP-2 and MMP-9, which at the same time translates into the course of angiogenesis and the formation of gastric cancer metastases (Zhang et al., 2012).

While VEGF is involved in regulating the secretion of MMPs, especially MMP-9, some of the MMPs secreted by stromal cells and tumor cells can regulate the secretion of VEGF. This is confirmed by the finding by Kudo et al. (2012) that the relationship between MMP-13 of neoplastic origin and VEGF produced by fibroblasts and endothelial cells, which in turn leads to the stimulation of angiogenesis in vivo.
Many MMPs are involved in the angiogenesis process. As mentioned above, MMP-9 releases VEGF and FGF- $\beta 2$ from the ECM. MMP-1 increases the expression of both VEGF and the VEGF receptor (VEGFR2). MMP-2 and MMP-9 degrade basement membranes and allow migration of endothelial cells. MMP-1 and MMP-8 are involved in the proliferation of endothelial cells during angiogenesis. MMP-2 and MMP-14 shape the lumen of new vessels, and MMP-14 and MMP9 contribute to the recruitment of pericytes that stabilize the newly formed vessels (Kudo et al., 2012; Fields, 2019; Quintero-Fabián et al., 2019).

\section{MATRIX METALLOPROTEINASES IN BLADDER CANCER}

Despite the dynamic development of diagnostic and therapeutic methods, prognosis of a 5-year survival in patients with bladder cancer is still unsatisfactory. Bladder cancer is the 7 th most common cancer in the male population and the 11th most common cancer in the world. The incidence rate (per 100,000 people per year) is 9.0 for men and 2.2 for women. In Europe, the highest incidence rate is in Belgium (31 in men and 6.2 in women) and the lowest in Finland (18.1 in men and 4.3 in women) (Burger et al., 2013; Jabłonowski 2013; van Osch et al., 2016; Cumberbatch et al. 2018; Babjuk et al., 2019). In Poland, bladder cancer is the 4th most common cancer in men and accounts for $7 \%$ of all malignant neoplasms, and in women it accounts for $2 \%$ of malignant tumors. The vast majority of cancers are diagnosed in patients over 50, and over $60 \%$ are in the elderly population (over 65). The risk of developing bladder cancer increases with age and is almost 3-4 higher in men than in women. According to the National Cancer Registry, the peak incidence in the group of men is at the 9th decade of life, and in women at the 8th decade of life. Bladder cancer causes $5 \%$ of deaths in men and $2 \%$ in women from neoplastic causes (Wojciechowska \& Dzidkowska, accessed on January 18, 2021).

It has been proven that the incidence of bladder cancer depends on many factors. Among them, cigarette smoking occupies a key position, which affects approximately $50 \%$ of patients with bladder cancer. There are no conclusive data on e-cigarettes, however, carcinogens are also detectable in urine in people who use this form of cigarettes. The second most frequent risk factor is occupational exposure to aromatic amines and polycyclic hydrocarbons, which mainly affect people working in the oil industry related to paints, varnishes, metal, and fuel processing. Exposure to ionizing radiation also promotes the development of bladder cancer (including patients receiving pelvic radiation therapy). Endemic infections caused by schistosomal flukes causing chronic cystitis are also considered to be the cause of the development of bladder cancer (Burger et al., 2013; van Osch et al., 2016; Cumberbatch et al., 2018; Babjuk et al., 2019).

At diagnosis, approximately $75 \%$ of patients have disease confined to the mucosa (pTa, CIS) or submucosa (p'T1). The percentage of patients with bladder muscle non-infiltrative disease (p'Ta, CIS, p'T1) is even higher in people under 40 (Jabłonowski, 2013). Currently, there are several forms of bladder cancer treatment: surgery, chemotherapy, radiotherapy, and immunotherapy. A special part is played by radical cystectomy, which is the standard treatment for cancer infiltrating the bladder muscle. Unfortunately, almost $50 \%$ of patients undergoing cystectomy, will develop metastases within 2 years of 
Table 1. Matrix metalloproteinases in bladder cancer

\begin{tabular}{|c|c|c|c|c|}
\hline MMP & Tested material & Laborathory method & Results & References \\
\hline MMP-2 & tumor tissue & zymography & $\begin{array}{l}\text { Higher expression of the active } \\
\text { form of MMP-2 in low differen- } \\
\text { tiated and high clinically advan- } \\
\text { ced tumors. }\end{array}$ & Kanda et al., 2000 \\
\hline MMP-9 & tumor tissue & ELISA & $\begin{array}{l}\text { Higher expression of MMP-9 in } \\
\text { low differentiated tumors. }\end{array}$ & Wu et al., 2018 \\
\hline MMP-28 & tumor tissue & $\begin{array}{l}\text { immunohistochemical me- } \\
\text { thods }\end{array}$ & $\begin{array}{l}\text { Higher expression in high cli- } \\
\text { nically advanced tumors. High } \\
\text { expression correlates with shor- } \\
\text { ter survival times. }\end{array}$ & Wang et al., 2020 \\
\hline $\begin{array}{l}\text { MMP-2, } \\
\text { MMP-9, } \\
\text { TIMP-1 } \\
\text { TIMP-2 }\end{array}$ & $\begin{array}{l}\text { urine } \\
\text { serum }\end{array}$ & ELISA & $\begin{array}{l}\text { Higher expression of MMP-2, } \\
\text { MMP-9, TIMP-1 and TIMP-2 in } \\
\text { the study group. }\end{array}$ & Ricci et al., 2015 \\
\hline MMP-7 & urine & Western-blot & $\begin{array}{l}\text { High expression of MMP-7 in } \\
\text { the group of patients with me- } \\
\text { tastases. }\end{array}$ & Szarvas et al., 2011 \\
\hline $\begin{array}{l}\text { MMP-3 } \\
\text { MMP-9 }\end{array}$ & urine & ELISA & $\begin{array}{l}\text { High expression in the test gro- } \\
\text { up. MMP-3 is highly expressed } \\
\text { early in the disease. }\end{array}$ & El-Sharkawi et al., 2014 \\
\hline $\begin{array}{l}\text { MMP-14 } \\
\text { MMP-15 }\end{array}$ & tumor tissue & $\begin{array}{l}\text { ELISA } \\
\text { Western-blot }\end{array}$ & $\begin{array}{l}\text { Higher expression of MMP- } \\
14 \text { and MMP-15 in the study } \\
\text { group. }\end{array}$ & Kudelski et al., 2020 \\
\hline
\end{tabular}

surgery and will die of the underlying disease (Anghel et al. 2016).

There are many studies on MMPs in bladder cancer (Table 1). Most studies have been devoted to MMP-2 and MMP-9, i.e. enzymes responsible for the degradation of type IV collagen in the first place, which, through the destruction of basement membranes and ECM, play an essential role in the process of tumor invasion (Kanda et al., 2000; Opdenakker et al., 2001; Kurzepa et al., 2014; Wu et al., 2018).

In a study by Kanda and others (Kanda et al., 2000) the activity of MMP-2 using zymography in bladder tumor tissue collected from 61 patients was assessed. The correlations between the amount of active and total MMP-2 form, and the degree of histological differentiation (G1, G2, G3), and the clinical advancement of the tumor according to TNM were examined (Table 2). Expression of the active form of MMP-2 was higher in the group of G3 tumors than in G2 and G1 tumors, while no significant difference was found between G2 and G1 tumors (Table 3). Mean expression of the active form of MMP-2 also increased with clinical advancement. Significantly higher expression of the active form of MMP2 was found in the bladder muscle invasive disease ( $>$ pT1) than in non-invasive tumors (pTa, p'T1, CIS). Similar conclusions were observed by Wu et al. (2018) in relation to MMP-9 in tumour tissue. MMP-9 activity was tested by immunohistochemistry and ELISA. Tumour tissue was used in the research group, while in the control group the normal bladder mucosa was at least $3 \mathrm{~cm}$ away from the tumour. MMP-9 expression was found in $57.6 \%$ of patients in the research group, compared to $6.3 \%$ in the control group. It was confirmed that the expression of MMP-9 was statistically higher in G3 tumors (poorly differentiated) than in G1 and G2. There were no differences between G1 and G2 tumors. Age and gender had no effect on MMP-9 expression. The positive correlation between the degree of MMP-9 expression and the degree of histological differentiation of the tumor was emphasized, therefore MMP-9 can be used as a potential marker of malignancy of bladder tumors.
Table 2. The TNM classification of bladder cancer (Colombel et al., 2008 modified)

\begin{tabular}{|c|c|}
\hline \multicolumn{2}{|c|}{$\mathrm{T}$ - primary tumor } \\
\hline Tx & Primary tumor cannot be assessed \\
\hline T0 & No evidence of primary tumor \\
\hline Ta & Noninvasive papillary carcinoma \\
\hline Tis & Carcinoma in situ \\
\hline T1 & $\begin{array}{l}\text { Tumor invades subepithelial connective } \\
\text { tissue (lamina propria) }\end{array}$ \\
\hline $\mathrm{T} 2$ & $\begin{array}{l}\text { Tumor invades muscle (muscularis propria) } \\
\text { T2a tumor invades superficial muscle (inner } \\
\text { half) } \\
\text { T2b tumor invades deep muscle (outer half) }\end{array}$ \\
\hline T3 & $\begin{array}{l}\text { Tumor invades perivesical tissue } \\
\text { T3a microscopic } \\
\text { T3b macroscopic (extravesical mass) }\end{array}$ \\
\hline T4 & $\begin{array}{l}\text { Invasion of adjacent structures } \\
\text { T4a tumor invades prostate, uterus, vagina } \\
\text { T4b tumor invades pelvic or abdominal wall }\end{array}$ \\
\hline \multicolumn{2}{|c|}{$\mathrm{N}$ - lymph nodes } \\
\hline Nx & Regional nodes cannot be assessed \\
\hline No & No regional lymph node disease \\
\hline N1 & Metastasis in single node $2 \mathrm{~cm}$ or less \\
\hline N2 & $\begin{array}{l}\text { Metastasis in single or multiple nodes be- } \\
\text { tween } 2-5 \mathrm{~cm}\end{array}$ \\
\hline N3 & $\begin{array}{l}\text { Metastasis in lymph node greater than } 5 \\
\mathrm{~cm}\end{array}$ \\
\hline \multicolumn{2}{|c|}{ M - metastasis } \\
\hline Mx & Distant metastasis cannot be assessed \\
\hline Mo & No distant metastasis \\
\hline M1 & Distant metastasis \\
\hline
\end{tabular}

In a study by Wang et al. (2020) they assessed the activity of MMP-28 in biopsy samples from bladder cancer patients and compared it to normal bladder mucosa. 
Table 3. The WHO histological grading of bladder cancer (Pasin et al., 2008 modified)

\begin{tabular}{ll}
\hline Grade & Microscopic characteristics \\
\hline G1 & the cancer cells look very similar to normal bladder cells, they are usually slow-growing and are less likely \\
to spread
\end{tabular}

MMP activity was assessed in tumour tissue by immunohistochemical methods. Significantly increased expression of MMP-28 was found in patients with multiple tumors, deep infiltration (pT2-pT4), large tumour diameter, lymph node metastases and distant metastases. Moreover, patients with elevated MMP-28 expression had a significantly shorter (35.65 \pm 1.47 months) survival time than patients with low MMP-28 expression (5636 125 months). MMP-28, called epilysin, belongs to the subfamily MMP-19. MMP-28 plays an important role in the development of some neoplasms, and its expression has been confirmed in colon, pancreatic, ovarian, prostate and lung cancer cells (Marchenko \& Strongin, 2001).

In addition to examining the expression of MMPs directly in the tumour tissue, the activity of MMPs in urine and serum was assessed in patients with bladder cancer. In a study by Ricci and others (Ricci et al., 2015), MMP-2, MMP-9, TIMP-1, TIMP-2 in urine and blood serum were determined. The study used a morning urine sample and blood serum from patients before treatment. Commercial ELISA tests were used to measure MMPs and TIMPs. There was no presence of MMP-2, MMP9, TIMP -1, TIMP-2 in urine and blood samples in patients from the control group. In the group of bladder cancer patients, increased MMP-2 activity was observed in 63\% (26 out of 41 patients) and MMP-9 in 61\% (25 out of 41 patients). The mean concentration in urine was $1.27 \mathrm{ng} / \mathrm{ml}$ and $1.30 \mathrm{ng} / \mathrm{ml}$ for MMP-2 and MMP-9, respectively. Compared to MMPs, the presence of TIMP1 and TIMP-2 was found in a higher percentage of patients (95\% and 83\%, respectively). The concentration of TIMP-1 in urine was significantly higher in the group of G3 tumors than in G1 tumors. Moreover, a higher concentration of TIMP-1 was observed in the group of T1 tumors than in $\mathrm{Ta}$ tumors. In contrast to TIMP-1, the concentration of TIMP-2 in urine did not show a significant difference between low- and well-differentiated tumors and did not depend on the clinical stage.

Durkan and others (Durkan et al., 2001) found higher TIMPs expression in urine in the group of bladder cancer patients than in the control group, with higher concentrations in the group of patients with infiltrating bladder cancer than in the group of non-invasive tumors (Ta, T1, CIS). There were no differences depending on the degree of histological differentiation of the tumour. Monier et al. (2002) came to different conclusions, finding lower concentrations of TIMP-1 in the group of patients with T1-T4 bladder cancer than in patients with Ta grade bladder cancer.

In the analysis of MMP-3 and MMP-9 concentrations in urine by El-Sharkawi and others (El-Sharkawi et al., 2014) found significantly higher concentrations of MMPs in the group of bladder cancer patients compared to the control group of healthy patients. However, MMP-3 showed high concentrations in the earlier stages of tumour development (T1 and T2), which remained high in the more advanced forms (T3 and T4), while MMP9 was highly expressed in advanced bladder tumors (T3 and T4). It was emphasized that MMP-3 may be used in the future as a marker of early forms of bladder cancer.

In the analysis of MMP-7 concentration in urine in patients with bladder cancer by Szarvas and others (Szarvas et al., 2011), no difference in the concentrations of the tested MMP was found between the group of patients with cancer confined to the bladder and the control group of healthy patients, while in the group of patients with distant metastases, the concentration of MMP-7 was 4 times higher than in the control group.

Kudelski and others (Kudelski et al., 2020) analyzed the activity of membrane metalloproteinases (MMP-14 and MMP-15) and the concentration of TIMP-1 in the tissue of bladder tumors and in healthy bladder tissue. For this purpose, ELISA tests and the Western-blot method were used. The MMP-14 activity in the control group was $7.35 \mathrm{mg} / \mathrm{kg}$ of protein. Both low-grade and high-grade tumors showed increased activity of MMP14, while in low-grade tumors the activity of the tested MMP was about 35\% higher, and in high-grade tumors almost 10 times higher than in the control group. The activity of MMP-15 was approximately 3 times higher than that of MMP-14 in the control group. Low-grade tumors were characterized by increased MMP-15 activity, while in the high-grade neoplasms, MMP-15 activity was $4 \mathrm{mg} / \mathrm{kg}$ lower than in the control tissue. The lowest concentration of TIMP-1 was found in healthy bladder tissue. The TIMP-1 concentration was the highest in the low-grade neoplasm group (almost 75\% higher than in the control group), while in the high-grade group the TIMP-1 concentration decreased significantly but was still higher than in the control group. The authors emphasize the role of MMP-14 as a risk factor for the development of metastatic disease.

\section{DISCUSSION}

In 28 countries of the European Union, more than 120,000 people are diagnosed with bladder cancer every year, and over 40,000 people die from this cancer every year. In the EU, EUR 4.9 billion was spent in 2012 on the treatment of bladder cancer, which accounted for $5 \%$ of all cancer-related health care expenditure (Leal et al., 2016).

Numerous studies confirm the relationship between the expression of MMPs and the development of malignant tumors. MMPs take part in the angiogenesis process, participate in tumour invasion, local infiltration, and the formation of distant metastases. Hence, they become a potential target for drug action. Blocking the expression or activity of MMPs may be a future treatment strategy for cancer patients. An example would be an anti-MMP-14 monoclonal antibody that prevents proMMP-2 activation or an antibody that binds to the hemopexin domain of MMP-2 (Yang et al., 2016).

Chemically modified tetracyclines that have lost their antimicrobial activity are inhibitors of MMPs by binding calcium and zinc. Chemically modified doxycycline is now approved by the Food and Drug Administration 
(FDA) as an inhibitor of MMP-7 and MMP-8, which are involved in the pathogenesis of periodontal disease $(\mathrm{Li}$ et al., 2013). Metastat blocks the activity of MMP-1, MMP2, MMP3, MMP-7, MMP-9 and MMP-12 and is used to treat Kaposi's sarcoma developing in patients with acquired immune deficiency syndrome (AIDS) (Dezube et al., 2006).

Some substances have the additional function of reducing the enzymatic activity of MMPs. Among them, mention may be made of bisphosphonates, which are used to prevent bone resorption. Zolendronic acid, used in the treatment of patients with prostate cancer with bone metastases, has the ability to block the activity of MMP-2, MMP-9, MMP-12, MMP-14, and MMP-15 (Li et al., 2012).

Since bladder cancer is characterized by the ability to recur, from the point of view of clinical practice, it seems particularly important to develop a marker of early bladder tumor recurrence. MMPs detected in the urine of bladder cancer patients are potential factors that could perform this role. In the works of numerous authors, elevated concentrations of MMPs in the urine in the course of neoplastic disease are found (Szarvas et al., 2011; El-Sharkawi et al. 2014; Ricci et al. 2015; Fouad et al., 2019).

In summary, MMPs play an important role in the development of neoplastic disease, including bladder cancer. Increased expression of MMPs is associated with invasion and metastasis. MMPs can be used as prognostic factors in bladder cancer. The potential treatment of tumors by targeting TIMPs and MMPs, and the use of MMPs as markers of early relapse, requires further research.

\section{Conflict of interests}

The authors have no potential conflicts of interest to declare

\section{REFERENCES}

Anghel RM, Gales LN, Trifanescu OG (2016) Outcome of urinary bladder cancer after combined therapies. J Med Life 9: 153-159

Ardi VC, Van den Steen PE, Opdenakker G, Schweighofer B, Deryugina EI, Quigley JP (2009) Neutrophil MMP-9 proenzyme, unencumbered by TIMP-1, undergoes efficient activation in vivo and catalytically induces angiogenesis via a basic fibroblast growth factor (FGF-2)/FGFR-2 pathway. J Biol Chem 284: 25854-25866. https:// doi.org/10.1074\%2Fjbc.M109.033472

Arza B, De Maeyer M, Félez J, Collen D, Lijnen HR (2001) Critical role of glutamic acid 202 in the enzymatic activity of stromelysin-1 (MMP-3). Eur J Biochem 268: 826-831. https://doi.org/10.1046/ j.1432-1327.2001.01943.x

Babjuk M, Burger M, Compérat EM, Gontero P, Mostafid AH, Palou J, van Rhijn BWG, Rouprêt M, Shariat SF, Sylvester R, Zigeuner $\mathrm{R}$, Capoun $\mathrm{O}$, Cohen D, Escrig JLD, Hernández V, Peyronnet B, Seisen T, Soukup V (2019) European association of urology guidelines on non-muscle-invasive bladder cancer (TaT1 and Carcinomai in situ) - 2019 Update. Eur Urol 76: 639-657. https://doi. org/10.1016/j.eururo.2019.08.016

Batra J, Robinson J, Soares AS, Fields AP, Radisky DC, Radisky ES (2012) Matrix metalloproteinase-10 (MMP-10) interaction with tissue inhibitors of metalloproteinases TIMP-1 and TIMP-2: binding studies and crystal structure. J Biol Chem 287: 15935-15946. https:// doi.org/10.1074/jbc.M112.341156

Bauvois B (2012) New facets of matrix metalloproteinases MMP-2 and MMP-9 as cell surface transducers: outside-in signaling and relationship to tumor progression. Biochim Biophys Acta 1825: 29-36. https://doi.org/10.1016/j.bbcan.2011.10.001

Bhoopathi P, Chetty C, Gujrati M, Dinh DH, Rao JS, Lakka SS (2010) The role of MMP-9 in the anti-angiogenic effect of secreted protein acidic and rich in cysteine. Br J Cancer 102: 530-540. https://doi. org/10.1038/sj.bjc.6605538

Bolon I, Devouassoux M, Robert C, Moro D, Brambilla C, Brambilla E (1997) Expression of urokinase-type plasminogen activator, stromelysin-1, stromelysin-3 and matrilysin genes in lung carcinomas. Am J Pathol 150: 1619-1629

Bremnes RM, Dønnem T, Al-Saad S, Al-Shibli K, Andersen S, Sirera R, Camps C, Marinez I, Busund LT (2011) The role of tumor stro$\mathrm{ma}$ in cancer progression and prognosis: emphasis on carcinomaassociated fibroblasts and non-small cell lung cancer. J Thorac Oncol 6: 209-217. https://doi.org/10.1097/JTO.0b013e3181f8a1bd

Brew K, Dinakarpandian D, Nagase H (2000) Tissue inhibitors of metalloproteinases: evolution, structure, and function. Biochim Biophys Acta 1477: 267-283. https://doi.org/10.1016/s0167-4838(99)002794

Brew K, Nagase H (2010) The tissue inhibitors of metalloproteinases (TIMPs): an ancient family with structural and functional diversity. Biochim Biophys Acta 1803: 55-71. https://doi.org/ 10.1016/j.bbamcr.2010.01.003

Bryda J, Wattroba S (2018) The proinflammatory role of lipoxygenases in rheumatoid arthritis. J Pre Clin Clin Res 12: 129-134. https://doi. org/10.26444/jpccr/99597

Burger M, Catto JW, Dalbagni G, Grossman HB, Herr H, Karakiewicz P, Kassouf W, Kiemeney LA, La Vecchia C, Shariat S, Lotan Y (2013) Epidemiology and risk factors of urothelial bladder cancer. Eur Urol 63: 234-241. https://doi.org/10.1016/j.eururo.2012.07.033

Cauwe B, Opdenakker G (2010) Intracellular substrate cleavage: a novel dimension in the biochemistry, biology, and pathology of matrix metalloproteinases. Crit Rev Biochem Mol Biol 45: 351-423. https:// doi.org/10.3109/10409238.2010.501783

Chang ZK, Meng FG, Zhang ZQ, Mao GP, Huang ZY, Liao WM, He AS (2018) MicroRNA-193b-3p regulates matrix metalloproteinase 19 expression in interleukin-1 $\beta$-induced human chondrocytes. $J$ Cell Biochem 119: 4775-4782. https://doi.org/10.1002/jcb.26669

Chetty C, Lakka SS, Bhoopathi P, Kunigal S, Geiss R, Rao JS (2008) Tissue inhibitor of matrix metalloproteinase 3 supresses tumor angiogenesis in matrix metalloproteinase 2-down-regulated lung cancer. Cancer Res 68: 4736-4745. https://doi.org/10.1158/0008-5472. CAN-07-6612

Chojnacki M, Zając A, Pięta M (2017) The involvement of matrix metalloproteinases in the development and progression of neoplasm diseases. Postepy Biochem 63: 277-286

Colombel M, Soloway M, Akaza H, Böhle A, Palou J, Buckley R, Lamm D, Brausi M, Witjes JA, Persad R (2008) Epidemiology, staging, grading, and risk stratification of bladder cancer. Eur Urol Suppl 7: 618-626. https://doi.org/10.1016/j.eursup.2008.08.002

Cumberbatch MGK, Jubber I, Black PC, Esperto F, Figueroa JD, Kamat AM, Kiemeney L, Lotan Y, Pang K, Silverman DT, Znaor A, Catto JWF (2018) Epidemiology of bladder cancer: A systematic review and contemporary update of risk factors in 2018. Eur Urol 74: 784-795. https://doi.org/10.1016/j.eururo.2018.09.001

De Bock K, Cauwenberghs S, Carmeliet P (2011) Vessel abnormalization: another hallmark of cancer? Molecular mechanisms and therapeutic implications. Curr Opin Genet Dev 21: 73-79. https://doi. org/10.1016/j.gde.2010.10.008

Deryugina EI, Quigley JP (2006) Matrix metalloproteinases and tumor metastasis. Cancer Metastasis Rev 25: 9-34. https://doi.org/10.1007/ s10555-006-7886-9

Deryugina EI, Quigley JP (2015) Tumor angiogenesis: MMP-mediated induction of intravasation- and metastasis-sustaining neovasculature. Matrix Biol 44-46: 94-112. https://doi.org/10.1016/j.matbio.2015.04.004

Dezube BJ, Krown SE, Lee JY, Bauer KS, Aboulafia DM (2006) Randomized phase II trial of matrix metalloproteinase inhibitor COL-3 in AIDS-related Kaposi's sarcoma: an AIDS Malignancy Consortium Study. J Clin Oncol 24: 1389-1394. https://doi.org/10.1200/ JCO.2005.04.2614

Dofara SG, Chang SL, Diorio C (2020) Gene polymorphisms and circulating levels of MMP-2 and MMP-9: A review of their role in breast cancer risk. Anticancer Res 40: 3619-3631. https://doi. org/10.21873/anticanres.14351

Durkan GC, Nutt JE, Rajjayabun PH, Neal DE, Lunec J, Mellon JK (2001) Prognostic significance of matrix metalloproteinase-1 and tissue inhibitor of metalloproteinase-1 in voided urine samples from patients with transitional cell carcinoma of the bladder. Clin Cancer Res 7: 3450-3456

El-Sharkawi F, El Sabah M, Hassan Z, Khaled H (2014) The biochemical value of urinary metalloproteinases 3 and 9 in diagnosis and prognosis of bladder cancer in Egypt. J Biomed Sci 21: 72. https:// doi.org/10.1186/s12929-014-0072-4

English WR, Ireland-Zecchini H, Baker AH, Littlewood TD, Bennett MR, Murphy G (2018) Tissue inhibitor of metalloproteinase-3 (TIMP-3) induces FAS dependent apoptosis in human vascular smooth muscle cells. PLoS One 13: e0195116. https://doi. org/10.1371/journal.pone.0195116

Fic P, Zakrocka I, Kurzepa J, Stepulak A (2011) Matrix metalloproteinases and atherosclerosis. Postepy Hig Med Dosw 25: 16-27. https:// doi.org/10.5604/17322693.931536 
Fields GB (2019) Mechanisms of action of novel drugs targeting angiogenesis-promoting matrix metalloproteinases. Front Immunol 10: 1278. https://doi.org/10.3389/fimmu.2019.01278

Fouad H, Salem H, Ellakwa DE, Abdel-Hamid M (2019) MMP-2 and MMP-9 as prognostic markers for the early detection of urinary bladder cancer. J Biochem Mol Toxicol 33: e22275. https://doi. org/10.1002/jbt.22275

Franco C, Patricia HR, Timo S, Claudia B, Marcela H (2017) Matrix metalloproteinases as regulators of periodontal inflammation. Int $\mathrm{J}$ Mol Sci 18: 440. https://doi.org/10.3390/ijms18020440

Galis ZS, Khatri JJ (2002) Matrix metalloproteinases in vascular remodeling and atherosclerosis: the good, the bad, the ugly. Circ Res 90: 251-262

Gill SE, Pape MC, Khokha R, Watson AJ, Leco KJ (2003) A null mutation for Tissue Inhibitor of Metalloproteinases-3 (Timp-3) impairs murine bronchiole branching morphogenesis. Dev Biol 261: 313-323. https://doi.org/10.1016/s0012-1606(03)00318-x

Gonzalez-Avila G, Sommer B, Mendoza-Posada DA, Ramos C, Garcia-Hernandez AA, Falfan-Valencia R (2019) Matrix metalloproteinases participation in the metastatic process and their diagnostic and therapeutic applications in cancer. Crit Rev Oncol Hematol 137: 57-83. https://doi.org/10.1016/j.critrevonc.2019.02.010

Grzelczyk WL, Szemraj J, Józefowicz-Korczyńska M (2016) The matrix metalloproteinase in larynx cancer. Postepy Hig Med Dosw (Online) 70: 1190-1197

Huang H (2018) Matrix metalloproteinase-9 (MMP-9) as a cancer biomarker and MMP-9 biosensors: Recent advances. Sensors (Basel) 18: 3249. https://doi.org/10.3390/s18103249

Jabłonowski Z (2013) Urinary bladder cancer - epidemiology, diagnostics and treatment in XXIst century. Folia Medica Lodriensia 40: 31-52 (in Polish)

Kanda K, Takahashi M, Murakami Y, Kanayama H, Kagawa S (2000) The role of the activated form of matrix metalloproteinase-2 in urothelial cancer. BJU Int 86: 553-557. https://doi.org/10.1046/ j.1464-410x.2000.00734.x

Kapoor C, Vaidya S, Wadhwan V, Hitesh, Kaur G, Pathak A (2016) Seesaw of matrix metalloproteinases (MMPs). J Cancer Res Ther 12: 28-35. https://doi.org/10.4103/0973-1482.157337

Kim EM, Hwang O (2011) Role of matrix metalloproteinase-3 in neurodegeneration. I Neurochem 116: 22-32. https://doi.org/10.1111/ j.1471-4159.2010.07082.x

Kim HI, Lee HS, Kim TH, Lee JS, Lee ST, Lee SJ (2015) Growthstimulatory activity of TIMP-2 is mediated through c-Src activation followed by activation of FAK, PI3-kinase/AKT, and ERK1/2 independent of MMP inhibition in lung adenocarcinoma cells. Oncotarget 6: 42905-42922. https://doi.org/10.18632/oncotarget.5466

Kudelski J, Młynarczyk G, Darewicz B, Bruczko-Goralewska M, Romanowicz L (2020) Dominative role of MMP-14 over MMP15 in human urinary bladder carcinoma on the basis of its enhanced specific activity. Medicine (Baltimore) 99: e19224. https://doi. org/10.1097/MD.0000000000019224

Kudo Y, Iizuka S, Yoshida M, Tsunematsu T, Kondo T, Subarnbhesaj A, Deraz EM, Siriwardena SB, Tahara H, Ishimaru N, Ogawa I, Takata T (2012) Matrix metalloproteinase-13 (MMP-13) directly and indirectly promotes tumor angiogenesis. J Biol Chem 287: 3871638728. https://doi.org/10.1074/jbc.M112.373159

Kurzepa J, Baran M, Wątroba S, Barud M, Babula D (2014) Collagenases and gelatinases in bone healing. The focus on mandibular fractures. Curr Issues Pharm Med Sci 27: 121-126.

Kwiatkowski P, Godlewski J, Śliwińska-Jewsiewicka A, Kmieć Z (2009) Cell adhesion molecules in the process of cancerogenesis and metastasis. Pol Ann Med 16: 128-137. https://doi.org/10.1254/jip.75.215

Lambert E, Dassé E, Haye B, Petitfrère E (2004) TIMPs as multifacial proteins. Crit Rev Oncol Hematol 49: 187-198. https://doi. org/10.1016/j.critrevonc.2003.09.008

Leal J, Luengo-Fernandez R, Sullivan R, Witjes JA (2016) Economic burden of bladder cancer across the European Union. Eur Urol 69: 438-447. https://doi.org/10.1016/j.eururo.2015.10.024

Li W, Saji S, Sato F, Noda M, Toi M (2013) Potential clinical applications of matrix metalloproteinase inhibitors and their future prospects. Int J Biol Markers 28: 117-130. https://doi.org/10.5301/ jbm.5000026

Li XY, Lin YC, Huang WL, Hong CQ, Chen JY, You YJ, Li WB (2012) Zoledronic acid inhibits proliferation and impairs migration and invasion through downregulating VEGF and MMPs expression in human nasopharyngeal carcinoma cells. Med Oncol 29: 714-720. https://doi.org/10.1007/s12032-011-9904-1

Lipka D, Boratyński J (2008) MMP metalloproteinases. Structure and function. Postepy Hig Med Dosw 62: 328-336 (in Polish)

Loftus IM, Naylor AR, Bell PR, Thompson MM (2002) Matrix metalloproteinases and atherosclerotic plaque instability. Br J Surg 89: 680-694. https://doi.org/10.1046/j.1365-2168.2002.02099.x

Lu Y, Papagerakis P, Yamakoshi Y, Hu JC, Bartlett JD, Simmer JP (2008) Functions of KLK4 and MMP-20 in dental enamel formation. Biol Chem 389: 695-700. https://doi.org/10.1515/BC.2008.080
Madro A, Czechowska G, Słomka M (2012) The decrease of serum MMP-2 activity corresponds of alcoholic cirrhosis stage. Alcohol 46: 155-157. https://doi.org/10.1016/j.alcohol.2011.07.008

Manicone AM, Harju-Baker S, Johnston LK, Chen AJ, Parks WC (2011) Epilysin (matrix metalloproteinase-28) contributes to airway epithelial cell survival. Respir Res 12: 144. https://doi. org/10.1186/1465-9921-12-144

Marchenko GN, Strongin AY (2001) MMP-28, a new human matrix metalloproteinase with an unusual cysteine-switch sequence is widely expressed in tumors. Gene 265: 87-93. https://doi.org/10.1016/ s0378-1119(01)00360-2

Monier F, Mollier S, Guillot M, Rambeaud JJ, Morel F, Zaoui P (2002) Urinary release of 72 and $92 \mathrm{kDa}$ gelatinases, TIMPs, N-GAL and conventional prognostic factors in urothelial carcinomas. Eur Urol 42: 356-363. https://doi.org/10.1016/s0302-2838(02)00350-0

Mott JD, Werb Z (2004) Regulation of matrix biology by matrix metalloproteinases. Curr Opin Cell Biol 16: 558-564. https://doi. org/10.1016/j.ceb.2004.07.010

Murphy G, Houbrechts A, Cockett MI, Williamson RA, O'Shea M, Docherty AJ (1991) The N-terminal domain of tissue inhibitor of metalloproteinases retains metalloproteinase inhibitory activity. Biochemistry 30: 8097-8102. https://doi.org/10.1021/bi00247a001

Nagase H, Visse R, Murphy G (2006) Structure and function of matrix metalloproteinases and TIMPs. Cardiovasc Res 69: 562-573. https:// doi.org/10.1016/j.cardiores.2005.12.002

Noë V, Fingleton B, Jacobs K, Crawford HC, Vermeulen S, Steelant W, Bruyneel E, Matrisian LM, Mareel M (2001) Release of an invasion promoter E-cadherin fragment by matrilysin and stromelysin-1. J Cell Sci 114: 111-118

Okamoto T, Akuta T, Tamura F, van der Vliet A, Akaike T (2004) Molecular mechanism for activation and regulation of matrix metalloproteinases during bacterial infections and respiratory inflammation. Biol Chem. 385: 997-1006. https://doi.org/10.1515/ BC. 2004.130

Opdenakker G, van den Steen PE, van Damme J (2001) Gelatinase B: a tuner and amplifier of immune functions. Trends Immunol 22: 571-579. https://doi.org/10.1016/s1471-4906(01)02023-3

Ozenci V, Rinaldi L, Teleshova N, Matusevicius D, Kivisäkk P, Kouwenhoven M, Link H (1992) Metalloproteinases and their tissue inhibitors in multiple sclerosis. J Autoimmun 12: 297-303. https://doi. org/10.1006/jaut.1999.0285

Page-McCaw A, Ewald AJ, Werb Z (2007) Matrix metalloproteinases and the regulation of tissue remodelling. Nat Rev Mol Cell Biol 8: 221-233. https://doi.org/10.1038/nrm2125

Palosaari H, Pennington CJ, Larmas M, Edwards DR, Tjäderhane L, Salo T (2003) Expression profile of matrix metalloproteinases (MMPs) and tissue inhibitors of MMPs (TIMPs) in mature human odontoblasts and pulp tissue. Eur J Oral Sci 111: 1-11. https://doi. org/10.1034/j.1600-0722.2003.00026.x

Pasin E, Josephson DY, Mitra AP, Cote RJ, Stein JP (2008) Superficial bladder cancer: an update on etiology, molecular development, classification, and natural history. Rev Urol 10: 31-43

Peters JM, Gonzalez FJ (2018) The evolution of carcinogenesis. Toxicol Sci 165: 272-276. https://doi.org/10.1093/toxsci/kfy184

Pittayapruek P, Meephansan J, Prapapan O, Komine M, Ohtsuki M (2016) Role of matrix metalloproteinases in photoaging and photocarcinogenesis. Int J Mol Sci 17: 868. https://doi.org/10.3390/ ijms17060868

Quintero-Fabián S, Arreola R, Becerril-Villanueva E, Torres-Romero JC, Arana-Argáez V, Lara-Riegos J, Ramírez-Camacho MA, Alvarez-Sánchez ME (2019) Role of matrix metalloproteinases in angiogenesis and cancer. Front Oncol 9: 1370. https://doi.org/10.3389/ fonc. 2019.01370

Räsänen K, Vaheri A (2010) Activation of fibroblasts in cancer stroma. Exp Cell Res 316: 2713-2722. https://doi.org/10.1016/j.yexcr.2010.04.032

Ricci S, Bruzzese D, DI Carlo A (2015) Evaluation of MMP-2, MMP9, TIMP-1, TIMP-2, NGAL and MMP-9/NGAL complex in urine and sera from patients with bladder cancer. Oncol Lett 10: 25272532. https://doi.org/10.3892/ol.2015.3558

Schmidt R, Bültmann A, Ungerer M, Joghetaei N, Bülbül O, Thieme S, Chavakis T, Toole BP, Gawaz M, Schömig A, May AE (2006) Extracellular matrix metalloproteinase inducer regulates matrix metalloproteinase activity in cardiovascular cells: implications in acute myocardial infarction. Circulation 113: 834-841. https://doi.org/10.1161/ CIRCULATIONAHA.105.568162

Singh S, Mehta N, Lilan J, Budhthoki MB, Chao F, Yong L (2017) Initiative action of tumor-associated macrophage during tumor metastasis. Biochim Open 4: 8-18. https://doi.org/10.1016/j.biopen.2016.11.002

Song Y, Ye M, Zhou J, Wang Z, Zhu X (2019) Targeting E-cadherin expression with small molecules for digestive cancer treatment. $\mathrm{Am}$ J Transl Res 11: 3932-3944

Sun MX, Fu F, Gong ML, Fan GL, Liu CX (2018) Effects of curcumin on the role of MMP-2 in endometrial cancer cell proliferation 
and invasion. Eur Rev Med Pharmacol Sci 22: 5033-5041. https://doi. org/10.26355/eurrev_201808_15646

Szarvas T, Singer BB, Becker M, Vom Dorp F, Jäger T, Szendroi A, Riesz P, Romics I, Rübben H, Ergün S (2011) Urinary matrix metalloproteinase-7 level is associated with the presence of metastasis in bladder cancer. BJU Int 107: 1069-1073. https://doi.org/10.1111/ j.1464-410X.2010.09625.x

Taddei ML, Giannoni E, Comito G, Chiarugi P (2013) Microenvironment and tumor cell plasticity: an easy way out. Cancer Lett 341: 80-96. https://doi.org/10.1016/j.canlet.2013.01.042

Trojek J (2012) Extracellular matrix metalloproteases and their tissue inhibitors. Postepy Biochem 58: 353-362 (in Polish)

Valastyan S, Weinberg RA (2011) Tumor metastasis: Molecular insights and evolving paradigms. Cell 147: 275-292. https://doi. org/10.1016/j.cell.2011.09.024

van Hove I, Lemmens K, van de Velde S, Verslegers M, Moons L (2012) Matrix metalloproteinase-3 in the central nervous system: a look on the bright side. I Neurochem 123: 203-216. https://doi. org/10.1111/j.1471-4159.2012.07900.x

van Osch FH, Jochems SH, van Schooten FJ, Bryan RT, Zeegers MP (2016) Quantified relations between exposure to tobacco smoking and bladder cancer risk: a meta-analysis of 89 observational studies. Int J Epidemiol 45: 857-870. https://doi.org/10.1093/ije/dyw044

Verslegers M, Lemmens K, van Hove I, Moons L (2013) Matrix metalloproteinase- 2 and -9 as promising benefactors in development, plasticity, and repair of the nervous system. Prog Neurobiol 105: 6078. https://doi.org/10.1016/j.pneurobio.2013.03.004

Wang H, Wu JX, Chen XP, Zhang Q, Wei HB, Wang HJ, Yang X, Zhang DH (2020) Expression and clinical significance of MMP-28 in bladder cancer. Technol Cancer Res Treat 19: 1533033820974017. https://doi.org/10.1177/1533033820974017

Watroba S, Kocot J, Bryda J, Kurzepa J (2019) Serum activity of MMP-2 and MMP-9 and stromielisin-1 concentration as predictors in the pathogenesis of bronchopulmonary dysplasia in preterm neonates. Postepy Hig Med Dosw 73: 703-712
Wattroba SJ, Bryda J (2019) Pathophysiological mechanisms and pharmacological methods of prevention and treatment of bronchopulmonary dysplasia in preterm infants. J Pre Clin Clin Res 13: 170-178. https://doi.org/10.26444/jpccr/114123

Wątroba S, Wiśniowski T, Bryda J, Kurzepa J (2021) Characteristics of matrix metalloproteinases and their role in embryogenesis of the mammalian respiratory system. Postepy Hig Med Dosw (Online) 75: in press

Wojciechowska U, Didkowska J. Zachorowania i zgony na nowotwory złośliwe w Polsce. Krajowy Rejestr Nowotworów, Narodowy Instytut Onkologii im. Marii Sketodowskiej-Curie - Państwowy Instytut Badawcry. Dostępne na stronie http://onkologia.org.pl/raporty dostęp z dnia 18/01/2021 (proszę podac angielska transkrypcję i rok)

Wu GJ, Bao JS, Yue ZJ, Zeng FC, Cen S, Tang ZY, Kang XL (2018) Elevated expression of matrix metalloproteinase- 9 is associated with bladder cancer pathogenesis. J Cancer Res Ther 14: 54-59. https:// doi.org/10.4103/0973-1482.163761

Wysocka A, Giziński S, Lechowski R (2014) Matrix metalloproteinases - their structure and function. Życie Weterynaryjne 89: 223-227 (in Poilsh)

Yang JS, Lin CW, Su SC, Yang SF (2016) Pharmacodynamic considerations in the use of matrix metalloproteinase inhibitors in cancer treatment. Expert Opin Drug Metab Toxicol 12: 191-200. https://doi. org/10.1517/17425255.2016.1131820

Zhang JL, Chen GW, Liu YC, Wang PY, Wang X, Wan YL, Zhu J, Gao HQ, Yin J, Wang W, Tian ML (2012) Secreted protein acidic and rich in cysteine (SPARC) suppresses angiogenesis by down-regulating the expression of VEGF and MMP-7 in gastric cancer. PLOS One 7: e44618. https://doi.org/10.1371/journal.pone.0044618

Zhou W, Yu X, Sun S, Zhang X, Yang W, Zhang J, Zhang X, Jiang Z (2019) Increased expression of MMP-2 and MMP-9 indicates poor prognosis in glioma recurrence. Biomed Pharmacother 118: 109369. https://doi.org/10.1016/j.biopha.2019.109369 